\title{
A Comparative Study of Biofuels and Fischer-Tropsch Diesel Blends on the Engine Combustion Performance for Reducing Exhaust Gaseous and Particulate Emissions
}

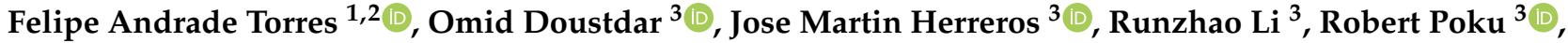 \\ Athanasios Tsolakis ${ }^{3}$, Jorge Martins ${ }^{4, *}$ (i) and Silvio A. B. Vieira de Melo ${ }^{1,5}[$
}

1 Industrial Engineering Program, Polytechnic School, Federal University of Bahia, Salvador 40210-630, Brazil; ftorres@ufrb.edu.br (F.A.T.); sabvm@ufba.br (S.A.B.V.d.M.)

2 Center of Exact and Technological Sciences, Department of Mechanical Systems, Federal University of Recôncavo of Bahia, Cruz das Almas 44380-000, Brazil

3 Department of Mechanical Engineering, School of Engineering, The University of Birmingham, Birmingham B15 2TT, UK; o.doustdar@bham.ac.uk (O.D.); j.herreros@bham.ac.uk (J.M.H.); rx1834@student.bham.ac.uk (R.L.); rxp798@student.bham.ac.uk (R.P.); a.tsolakis@bham.ac.uk (A.T.)

4 Mechanical Engineering Department, University of Minho, 4800-058 Guimaraes, Portugal

5 Interdisciplinary Center in Energy and Environment, Federal University of Bahia, Salvador 40170-115, Brazil

* Correspondence: jmartins@dem.uminho.pt

check for updates

Citation: Andrade Torres, F.; Doustdar, O.; Herreros, J.M.; Li, R.; Poku, R.; Tsolakis, A.; Martins, J.; Vieira de Melo, S.A.B. A Comparative Study of Biofuels and

Fischer-Tropsch Diesel Blends on the Engine Combustion Performance for Reducing Exhaust Gaseous and Particulate Emissions. Energies 2021, 14, 1538. https://doi.org/10.3390/ en14061538

Academic Editor: S M

Ashrafur Rahman

Received: 19 February 2021

Accepted: 5 March 2021

Published: 10 March 2021

Publisher's Note: MDPI stays neutral with regard to jurisdictional claims in published maps and institutional affiliations.

Copyright: (c) 2021 by the authors. Licensee MDPI, Basel, Switzerland. This article is an open access article distributed under the terms and conditions of the Creative Commons Attribution (CC BY) license (https:/ / creativecommons.org/licenses/by/ $4.0 /)$.

\begin{abstract}
The worldwide consumption of fossil hydrocarbons in the road transport sector in 2020 corresponded to roughly half of the overall consumption. However, biofuels have been discreetly contributing to mitigate gaseous emissions and participating in sustainable development, and thus leading to the extending of the commercial utilization of internal combustion engines. In this scenario, the present work aims at exploring the effects of alternative fuels containing a blend of $15 \%$ ethanol and 35\% biodiesel with a 50\% fossil diesel (E15D50B35) or 50\% Fischer-Tropsch (F-T) diesel (E15FTD50B35) on the engine combustion, exhaust emissions (CO, $\mathrm{HC}$, and $\mathrm{NO}_{\mathrm{x}}$ ), particulate emissions characteristics as well as the performance of an aftertreatment system of a common rail diesel engine. It was found that one of the blends (E15FTD50B35) showed more than 30\% reduction in PM concentration number, more than $25 \%$ reduction in mean particle size, and more than $85 \%$ reduction in total PM mass with respect to conventional diesel fuel. Additionally, it was found that the E15FTD50B35 blend reduces gaseous emissions of total hydrocarbons (THC) by more than $25 \%$ and $\mathrm{NO}$ by $3.8 \%$. The oxidation catalyst was effective in carbonaceous emissions reduction, despite the catalyst light-off being slightly delayed in comparison to diesel fuel blends.
\end{abstract}

Keywords: ethanol; Fischer-Tropsch diesel; exhaust emissions; aftertreatment system; particulate matter; diesel engine

\section{Introduction}

Transportation is a major energy consumption sector and should take a major role in the reduction of fossil fuel dependency and environmental pollution. The world energy consumption based on liquid fossil fuel sources shows that road transport corresponded to roughly half of the total, whilst others transport (e.g., aviation, rail, etc.) represented approximately 15\% [1]. Biofuels and electrification are among the alternatives to fossil fuel use in internal combustion engines (ICE). Electrification has been increasing in light-duty vehicles over the late years and, in a long-term scenario, is expected to partially replace liquid hydrocarbons in transport [2]. However, in the short-term, biofuels are still one of the most likely alternatives in decarbonizing and cleaning road transport. The European Union directive 2009/30/EC promotes the use of biofuels from 2020 while countries such as the USA, China, and Brazil also mandate the utilization of biofuels blended with conventional fuels [3]. Moreover, vehicle emissions including gaseous and particulate emissions are 
regulated while future legislation like the "Euro 7" standard is expected to be even more stringent [4].

Among the alternative biofuels, the most widely investigated is ethanol [5]. Emissions benefits have increased the interest for alcohol addition in diesel engines, especially ethanol, due to its high oxygen content [6]. Other interesting alternative biofuels are the synthetic Fischer-Tropsch (F-T) type fuels, manufactured from syngas yielding liquid straight-chain paraffin, and alternatively, after further processing, branched paraffin and cyclic hydrocarbon mixtures $[7,8]$. If the final liquid fuel is obtained from renewable sources, such as biomass, the fuel is called biomass-to-liquid (BTL). Natural gas (GTL) and coal (CTL) are also possible raw materials for the syngas (a mixture of $\mathrm{H}_{2}$ and $\mathrm{CO}$ ). According to the $\mathrm{H}_{2}$ and $\mathrm{CO}$ mixture percentage and the used catalyst, the reaction can produce gasoline-like or diesel-like fuels, the latter one called F-T diesel. F-T diesel is an ultra-clean fuel with a high cetane number $(\mathrm{CN})$, while promoting lower combustion temperatures. Further details regarding the effects of mixture compositions of syngas have been considered in [9].

Previous studies have evaluated the impact of blends of F-T diesel with fossil diesel [10], biodiesel [11], and diesel/biodiesel [12]. However, in the case of alcohol and F-T blends, most investigations have considered butanol [13]. Short-chain alcohols such as methanol and especially ethanol (which is a biofuel) have very significant availability, lower cost, and can be effectively used in compression ignition engines blended with diesel or biodiesel. It has been previously studied that blends of F-T diesel with alcohol have miscibility limitations. Lapuerta et al. [14] reported that blends of 5\% ethanol/95\% F-T diesel (E5FTD95) are stable for temperatures between $15-38^{\circ} \mathrm{C}$, although increasing the ethanol ratio diminished the blend stability, and the E10FTD90 blend is only stable at high temperatures $\left(>30^{\circ} \mathrm{C}\right)$. Hence, biodiesel has the benefits of helping to produce a stable blend and enhancing the lower lubricity of F-T diesel. Sun et al. [15] evaluated F-T diesel mixtures with methanol and reported that $\mathrm{CO}, \mathrm{NO}$, and soot were reduced. Yang et al. [16] studied the combustion characteristics of methanol/biodiesel/F-T diesel blends with n-decanol and reported that the ignition delay (ID) period was extended and peak heat release rate (HRR) was increased. Further, Jiao et al. [17] have studied a diesel engine fueled with methanol/Fischer-Tropsch diesel/biodiesel/diesel blends and reported lower PM, although slightly increased $\mathrm{NO}_{\mathrm{x}}$ emissions.

Rodríguez-Fernández et al. [18] have studied bioethanol port-fuel injection on a diesel engine fueled with F-T diesel and reported improved $\mathrm{NO}_{\mathrm{x}}$ and smoke emissions but $\mathrm{CO}$ and THC have increased. May-Carle et al. [19] assessed bioethanol/F-T diesel/biodiesel blend on a jet-stirred reactor. The focus was on numerical and experimental research of the kinetics of oxidation and concluded that further validation on a real engine would be required. Pidol et al. [20] had considered ethanol/biodiesel/Fischer-Tropsch diesel blend and a blend of those with the addition of iso-pentane on two engines. The researchers have reported that on the multi-cylinder engine both $\mathrm{CO}$ and $\mathrm{NO}_{\mathrm{x}}$ decreased although $\mathrm{HC}$ increased for the blend. Regarding the single-cylinder engine, all emissions increased for the tested blend.

In the near-future, complex energy scenarios using sustainably $\mathrm{CO}_{2}$ emissions in "green" energy production, storage, and distribution have been seen as a way to combat climate change. This can be promoted by utilizing renewable energy in the production of alcohols, ethers, esters, and synthetic clean fuels [21] with the use of novel and energyefficient catalytic systems. Apart from demonstrating that industrial production levels of these new fuels can be achieved, their efficient utilization will contribute to improving their design and contributing to the additional tank-to-wheel $\mathrm{CO}_{2}$ emissions reduction.

As previously mentioned, some studies have been conducted to evaluate the utilization of alcohol and F-T fuels in diesel engines. However, the reported studies focus on engine performance and exhaust emissions, but not on particulate matter (PM) characteristics, nor the interactions with the aftertreatment systems. Therefore, this study aims at investigating and understanding the effects of alternative fuels consisting of a blend of ethanol and F-T diesel (or fossil diesel) with the addition of biodiesel, on engine 
combustion, exhaust emissions $\left(\mathrm{CO}, \mathrm{HC}\right.$, and $\left.\mathrm{NO}_{\mathrm{x}}\right)$, particulate emissions formation, and characteristics as well as the aftertreatment system performance.

\section{Materials and Methods}

\subsection{Test Engine and Fuel Properties}

The study was carried out in a modern four-stroke, water-cooled based, single-cylinder diesel engine equipped with a high-pressure common-rail fuel injection system (Table 1). The fuel specifications and properties are listed in Table 2. The ultra-low sulfur diesel fuel (ULSD, with no added biodiesel) and the F-T diesel were supplied by Shell Global Solutions UK, the biodiesel was from Egogas Ltd. and the ethanol was purchased from Fisher Scientific Company. In order to evaluate the effect of the oxygen content in the combustion process in the blends, both ULSD and F-T diesel have been selected, due to having zero oxygen content. Ethanol fuel has high purity of $99.8 \%$. The biodiesel fuel was composed of a blend of vegetable-based esters, mainly rapeseed methyl ester ( $90 \%)$ blended with palm oil methyl ester $(\sim 10 \%)$.

Table 1. Test engine specifications.

\begin{tabular}{cc}
\hline Engine Parameters & Specifications \\
\hline Engine type & Diesel single-cylinder \\
Stroke type & Four-stroke \\
Number of cylinders & 1 \\
Cylinder bore $\times$ stroke $(\mathrm{mm})$ & $84 \times 90$ \\
Connecting rod length $(\mathrm{mm})$ & 160 \\
Compression ratio & $16: 1$ \\
Displacement $\left(\mathrm{cm}^{3}\right)$ & 499 \\
Engine speed range (rpm) & $900-2000$ \\
IMEP range (bar) & $<7$ \\
Fuel pressure range (bar) & $500-1500$ \\
Injection system & Common rail \\
\hline
\end{tabular}

A selected fuel blend composed of 15\% ethanol, 50\% Fischer-Tropsch diesel, and 35\% biodiesel, referenced as E15FTD50B35, was compared with a second blend, consisted of $15 \%$ ethanol, 50\% diesel, and 35\% biodiesel, was referenced as E15D50B35 and was also compared with conventional (pump) diesel fuel. All blends were previously prepared at the University of Birmingham and the base fuel constituents properties (physical and chemical) were either obtained through the fuel suppliers or by recent investigations of the research group [22,23]. These blends have been selected aiming to achieve four established targets.

1. To obtain a density based on the range for diesel fuel established in EN 590 by the European Committee for Standardization, with a value below biodiesel density and higher than F-T diesel;

2. To obtain a lower heating value (LHV) resembling the value for diesel fuel, with a value between that of the biodiesel and the F-T diesel. This would possibly prevent substantial variation in injection duration in comparison with pump diesel and therefore maintain the injection pattern of the engine [11];

3. To obtain a potential benefit related to the engine emissions by increasing oxygen content (both alternative fuels have the same oxygen content) and decreasing aromatic content;

4. The biodiesel fraction that was introduced has been chosen to balance the lower lubricity of ethanol that could influence the final blend value. 
Table 2. Specification of tested fuels.

\begin{tabular}{|c|c|c|c|c|c|c|}
\hline & ULSD & F-T Diesel & Ethanol & Biodiesel & E15FTD50B35 & E15D50B35 \\
\hline Chemical formula & $\mathrm{C}_{14} \mathrm{H}_{26.09}$ & $\mathrm{C}_{16.89} \mathrm{H}_{35.77}$ & $\mathrm{C}_{2} \mathrm{H}_{5} \mathrm{OH}$ & $\mathrm{C}_{18.96} \mathrm{H}_{35.92} \mathrm{O}_{2.9}$ & $\mathrm{C}_{15.52} \mathrm{H}_{31.53} \mathrm{O}_{1.24}$ & $\mathrm{C}_{14.13} \mathrm{H}_{26.88} \mathrm{O}_{1.21}$ \\
\hline Cetane number & 53.9 & 80 & 8 & 54.7 & $58.5^{1}$ & $47.7^{1}$ \\
\hline Lower heating value $[\mathrm{MJ} / \mathrm{kg}]$ & 42.7 & 43.9 & 26.8 & 37.4 & $38.9^{1}$ & $38.5^{1}$ \\
\hline Latent heat of vaporization $[\mathrm{kJ} / \mathrm{kg}]$ & 243 & 339 & 858 & 216 & - & - \\
\hline Density at $20^{\circ} \mathrm{C}\left[\mathrm{kg} / \mathrm{m}^{3}\right]$ & 827.1 & 784.6 & 789.4 & 883.7 & $820.01^{2}$ & $841.26^{2}$ \\
\hline Lubricity at $60^{\circ} \mathrm{C}[\mu \mathrm{m}]$ & 312 & 560 & 656 & 233 & ND & ND \\
\hline Stoichiometric fuel/air ratio & $1 / 14.55$ & $1 / 14.91$ & $1 / 9.00$ & $1 / 11.77$ & $1 / 13.20$ & $1 / 12.92$ \\
\hline Aromatics (wt \%) & 24.4 & 0.3 & 0 & $\sim 0$ & ND & ND \\
\hline $\mathrm{C}(\mathrm{wt} \%)$ & 86.5 & 84.8 & 52.14 & 77.2 & 77.31 & 78.03 \\
\hline $\mathrm{H}(\mathrm{wt} \%)$ & 13.5 & 15.2 & 13.13 & 12 & 13.68 & 12.96 \\
\hline $\mathrm{O}(\mathrm{wt} \%)$ & 0 & 0 & 34.73 & 10.8 & 9.0 & 9.0 \\
\hline
\end{tabular}

ND: not done; ${ }^{1}$ estimated based on the mass fraction [24]; ${ }^{2}$ estimated based on the volumetric fraction [24].

\subsection{Experimental Setup and Materials}

The engine test rig consisted of an electric dynamometer coupled to the engine. A schematic diagram of the experimental setup is shown in Figure 1. All tests were conducted at the Future Engines and Fuels Laboratory at the University of Birmingham. In-cylinder pressure was recorded over 200 cycles using an AVL GH13P pressure sensor mounted in the cylinder head and the signal was amplified by an AVL FlexIFEM 2P2 piezoelectric amplifier as well as monitored and stored on a PC for processing. A digital shaft encoder producing 360 pulses per revolution was used to measure the crankshaft position. The data from the crankshaft position and pressure were combined to create an in-cylinder pressure trace. A LabVIEW-based code was previously developed by the research group to control, collect, and monitor the data acquisition and combustion analysis. Besides, the other engine operating parameters, including multiple fuel injection strategies were controlled by using an in-house developed LabVIEW program [25]. The HRR was analyzed using the measured pressure data based on the first law of thermodynamics.

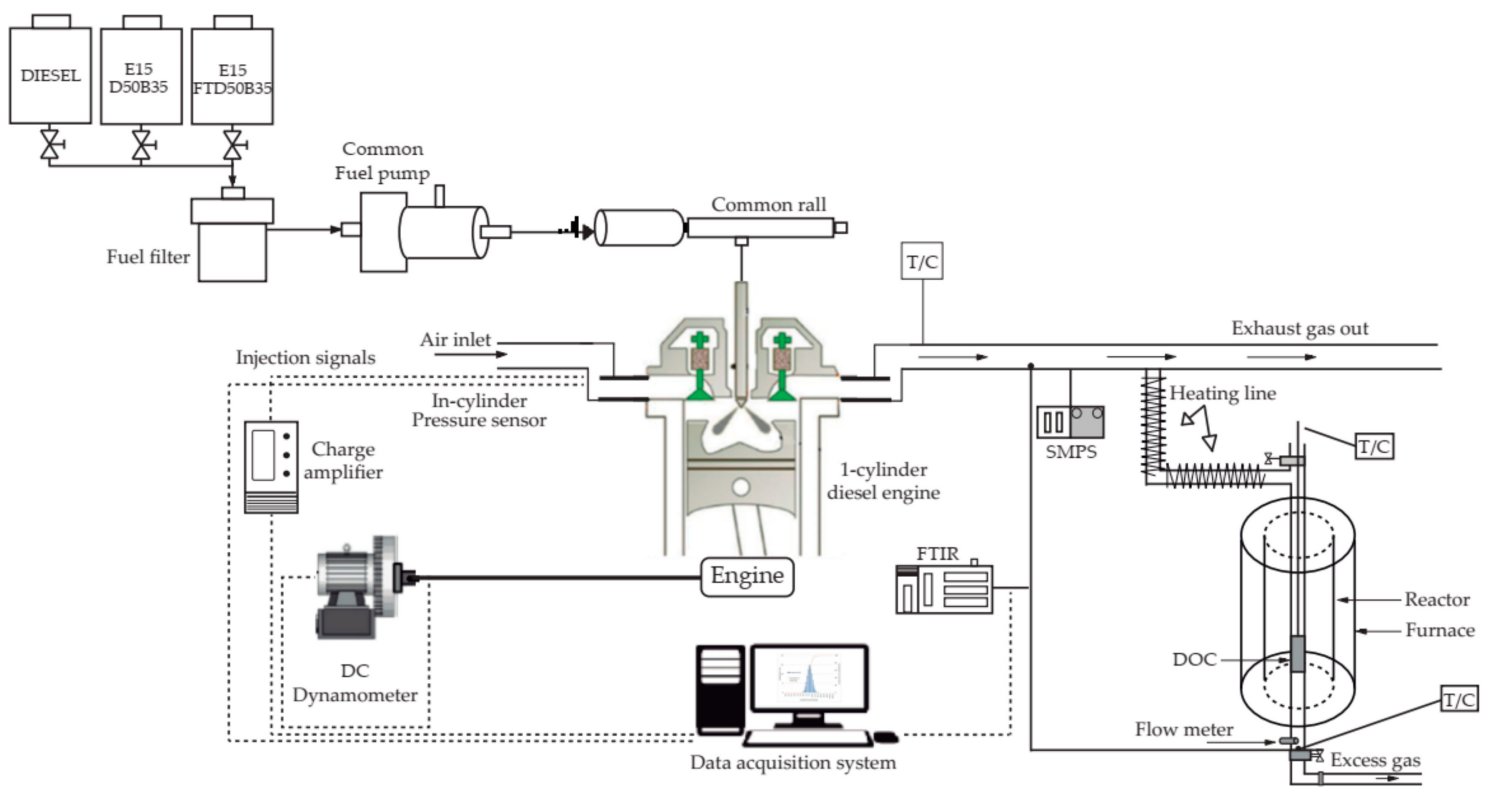

Figure 1. Schematic of the experimental facility.

The fuel was injected into the cylinder at a constant pressure of 550 bar, divided into the pilot (15 CAD BTDC, crank angle degree before top dead center) and main injection (5 CAD BTDC). Throughout the experiments, the indicated mean effective pressure (IMEP) was constantly controlled during changing fuels by updating the main fuel injection duration 
to maintain the same engine IMEP conditions for the base diesel fuel. A slightly longer fuel main injection was necessary for E15D50B35 and E15FTD50B35, as shown in Table 3. Tests were carried with the engine running with a fixed speed of $1500 \mathrm{rpm}$ and load set at 2 bar IMEP. The engine operational condition was selected based on a previous study of the research group, as it represents a frequent engine speed-load window in real vehicle driving cycles and provides a representative and stable condition of both gaseous emissions and exhaust temperature of the engine [25]. Moreover, the selection of this condition is due to the investigation focus on the fuel and not on the engine. The volumetric fuel consumption has been measured and later converted into mass fuel consumption using each fuel density value. The engine was warmed up to reduce the effects of emission variation during engine cold-start. Both fuel tanks and lines were cleaned and the engine was kept in operation for half an hour with the newly tested fuel, to minimize the influence from previously used fuels in the injection system.

Table 3. Fuel injection parameters and exhaust temperature.

\begin{tabular}{ccccccc}
\hline Fuel & $\begin{array}{c}\text { Injection } \\
\text { Pressure } \\
\text { (bar) }\end{array}$ & $\begin{array}{c}\text { Pilot Injection } \\
\text { Timing (CAD } \\
\text { BTDC) }\end{array}$ & $\begin{array}{c}\text { Injection } \\
\text { Duration (ms) }\end{array}$ & $\begin{array}{c}\text { Main Injection } \\
\text { Timing (CAD } \\
\text { BTDC) }\end{array}$ & $\begin{array}{c}\text { Injection } \\
\text { Duration } \\
\text { (ms) }\end{array}$ & $\begin{array}{c}\text { Engine-Out } \\
\text { Exhaust } \\
\text { Temperature }\left({ }^{\circ} \text { C) }\right.\end{array}$ \\
\hline Diesel & 550 & 15 & 0.150 & 5 & 0.499 & $236 \pm 2$ \\
E15D50B35 & 550 & 15 & 0.150 & 5 & 0.529 & $232 \pm 2$ \\
E15FTD50B35 & 550 & 15 & 0.150 & 5 & 0.546 & $235 \pm 2$ \\
\hline
\end{tabular}

A Fourier transform infrared (FTIR) spectrometry gas analyzer MKS MultiGas 2030 was used to measure gaseous exhaust emissions such as carbon monoxide (CO), carbon dioxide $\left(\mathrm{CO}_{2}\right)$, nitrogen oxides $\left(\mathrm{NO}_{\mathrm{x}}\right.$, assumed as the sum of $\mathrm{NO}$ and $\left.\mathrm{NO}_{2}\right)$, and total hydrocarbons (THC), among others. Particle size distributions were measured using a TSI scanning mobility particle sizer spectrometer (SMPS). The equipment is composed of a 3080 electrostatic classifier, a 3081 differential mobility analyzer (DMA), and a 3775 condensation particle counter (CPC) [26]. Part of the exhaust gas was sampled and diluted with air in a constant dilution ratio set at 1:20. The SMPS was connected downstream of the dilution system to extract a diluted sample for the particle size measurement.

The diesel oxidation catalyst (DOC) studies were carried out using a $24.3 \mathrm{~mm}$ in diameter and $101.5 \mathrm{~mm}$ in length and $0.10922 \mathrm{~mm}$ wall thickness monolith catalyst, with 0.258 cells $/ \mathrm{m}^{2}$, supplied by Johnson Matthey Plc. The catalyst was placed in a reactor inside a tubular furnace where K-type thermocouples (with a range of $0-1250{ }^{\circ} \mathrm{C}$ and an accuracy of $\pm 2.2^{\circ} \mathrm{C}$ ) and a TC-08 Thermocouple Data Logger (Pico Technology) were used to measure the engine exhaust temperature. A flow meter was responsible for controlling the exhaust gas flow. The details of the catalyst used in this study were a $4.237 \mathrm{~kg} / \mathrm{m}^{3}$ platinum:palladium (weight ratio $1: 1$ ) with alumina and zeolite washcoat $\left(158.66 \mathrm{~kg} / \mathrm{m}^{3}\right.$ loading). The effects of exhaust temperature and composition on the engine were investigated while the engine exhaust was maintained at a gas hourly space velocity (GHSV) of $35,000 \mathrm{~h}^{-1}$ and a heating temperature of about $5{ }^{\circ} \mathrm{C} / \mathrm{min}$.

\subsection{Error Analysis and Uncertainty Analysis}

Experimental evaluations usually have intrinsic associated uncertainties, as they are dependent on experimental conditions, instrument selection, and calibration, observation, data input, setup assembly, among other factors. Thus, an analysis of uncertainty is essential to validate results obtained from experimental results. The uncertainties have been calculated by the root-sum-square combination of the fixed errors introduced from different sources, with methods further described in [27], as shown in Equation (1) below:

$$
X_{i}=\bar{X}_{i} \pm U_{x}
$$


where $X_{i}$ is the actual value, $\bar{X}_{i}$ is the measured value and $U_{x}$ is the total uncertainty of the measurement, which may be calculated using Equation (2).

$$
U_{x}=\sqrt{\left(E_{S}\right)^{2} \pm\left(E_{r}\right)^{2}}
$$

where $E_{S}$ and $E_{r}$ are respectively the systematic and random errors. In general, those errors are provided by the instrument manufacturer specifications. As for the uncertainty associated when multiple measurements are obtained (e.g., exhaust emissions), it may be estimated by a statistical average, calculated as shown in Equation (3) below:

$$
X_{\text {average }}=\frac{\left(X_{1}+X_{2}+\ldots+X_{n}\right)}{n}
$$

where $X_{\text {average }}$ is the reported value, $X_{1}$ to $X_{n}$ are values measured within intervals and finally, $n$ is the total number of values. Moreover, the standard deviation (SD) of data is obtained using Equation (4).

$$
S D_{\text {mean /average }}=\frac{\sqrt{\sum_{i=1}^{n}\left(X_{i}-X_{\text {average }}\right)^{2}}}{1-n}
$$

Experimental uncertainty has been calculated and error bars have been added to graphs.

\section{Results and Discussions}

\subsection{Performance and Combustion Characteristics}

In order to obtain the same IMEP output for every tested fuel, it may be observed (Figure 2) that E15D50B35 and E15FTD50B35 blends have shown increased indicated specific fuel consumption (ISFC) of about $11.8 \%$ and $10.8 \%$ respectively in comparison with diesel (Figure 2). Higher ISFC can be associated with the LHV of the fuels, as pointed out by several studies with ethanol fuel blends $[5,28]$.

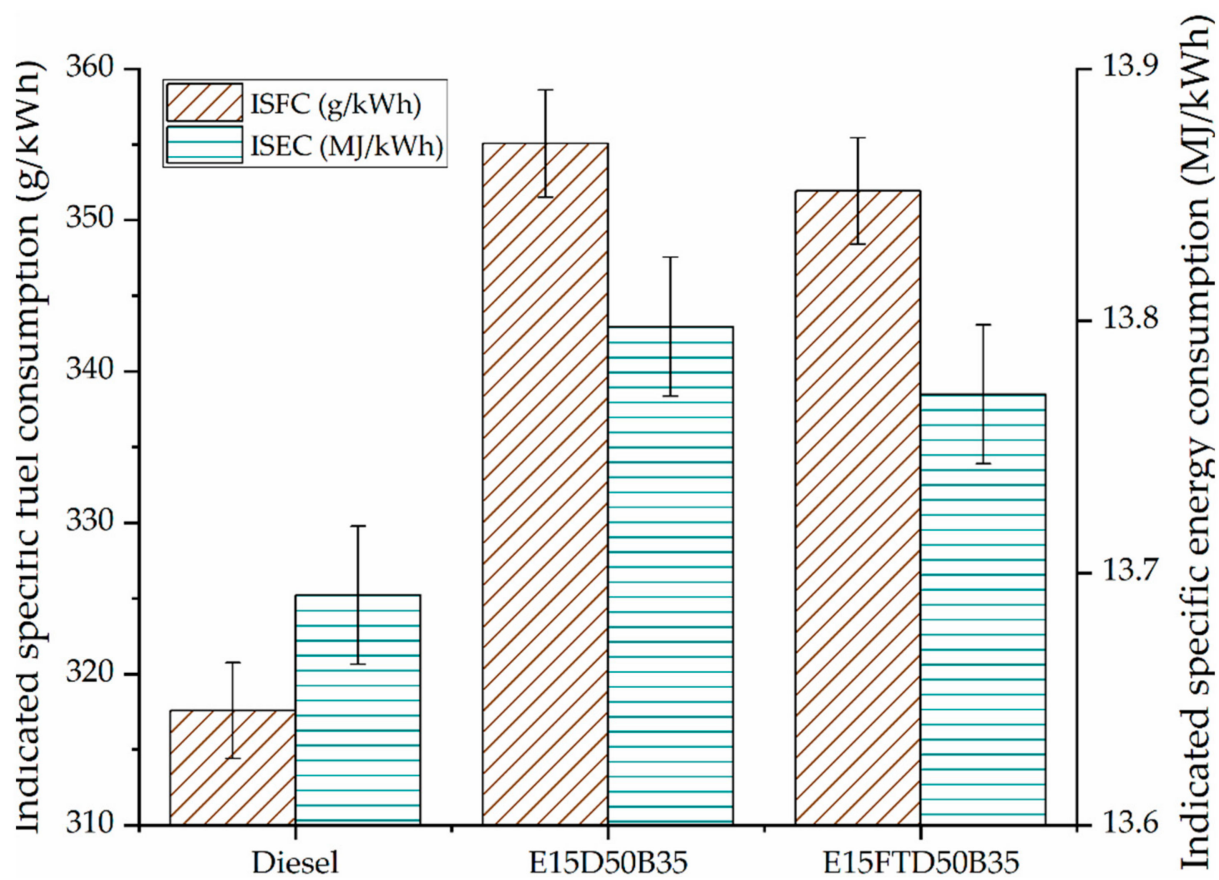

Figure 2. Indicated specific fuel consumption (ISFC) and indicated specific energy consumption (ISEC) for diesel, E15D50B35, and E15FTD50B35. 
On the other hand, indicated specific energy consumption (ISEC) is a more adequate parameter than ISFC to compare different fuels and for evaluating the potential of fueling the engine with ethanol blends (Figure 2).

ISEC indicates the amount of energy that is consumed to produce one unit of indicated work in one hour and it can be defined as the specific fuel consumption times the fuel LHV. Figure 2 shows the variation of ISEC for the engine fueled with diesel, E15D50B35, and E15FTD50B35. The blend of E15FTD50B35 showed a slightly higher ISEC (approximately $1.1 \%$ ) than diesel, whilst E15D50B35 has shown a $0.8 \%$ increase in value over diesel. Overall, the increase in ISFC for E15FTD50B35 is compensated by its LHV, which results in a percentually lower increase in ISEC. Other researchers have obtained similar results with other oxygenated fuels $[29,30]$.

Figure 3 shows the in-cylinder pressure and HRR versus the crank angle degree for the combustion of diesel, E15D50B35, and E15FTD50B35 at 2 bar IMEP and $1500 \mathrm{rpm}$. A significant increase in HRR, but later in the cycle, was obtained from the combustion of both alternative fuel blends, which may also explain the changes in emissions later to be discussed. As it may be seen, ethanol higher heat of vaporization has a direct effect on HRR peak and this seems to be in accordance with the literature [31]. Additionally, ethanol parameters such as heat of vaporization increase ID, and hence more fuel undergoes premixed combustion phase, promoting an increase in later HRR. The start of combustion was defined in accordance with the literature as the variation in inclination of the HRR curve, obtained from the cylinder pressure data [31]. The duration of combustion was characterized as the difference between CA10 (crank angle when 10\% accumulated HRR has occurred) and CA90 (crank angle when 90\% accumulated HRR has occurred). As for the duration of premixed combustion, it was assumed as the difference between CA10 and CA50 (crank angle when 50\% accumulated HRR has occurred).

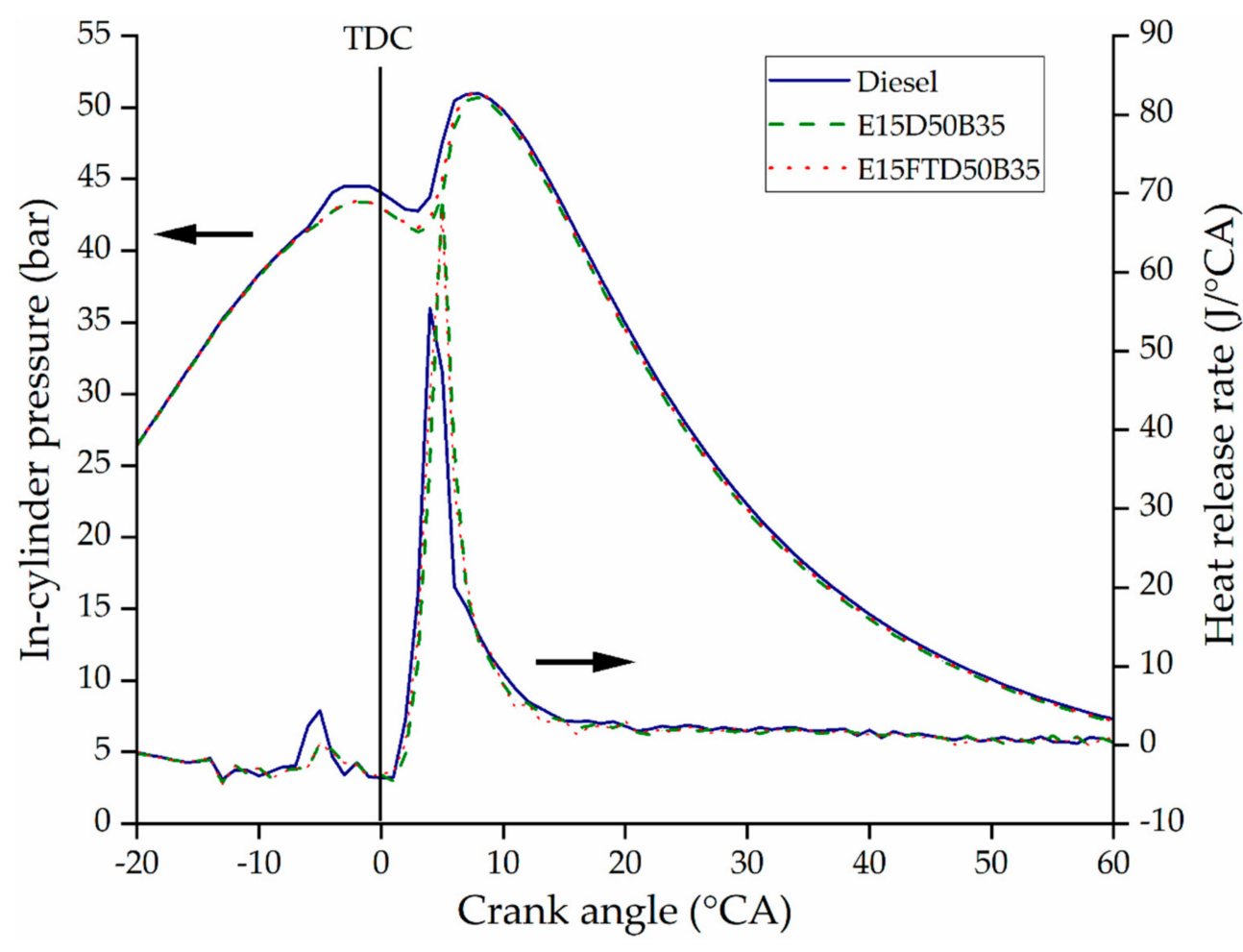

Figure 3. Effect of different fuel combustion on in-cylinder and heat release rate with a crank angle at 2 bar indicated mean effective pressure (IMEP) and $1500 \mathrm{rpm}$.

The peak in-cylinder pressures for diesel, E15D50B35, and E15FTD50B35 at 2 bar IMEP and $1500 \mathrm{rpm}$ are presented in Figure 4 for the 3 fuels. It was noticed that the ethanol addition to F-T resulted in a blended fuel with the highest peak pressure in comparison 
with the diesel fuel and the E15D50B35. In comparison with E15FTD50B35, the E15D50B35 blend had a slight reduction in peak pressure, in addition to the aforementioned increase in the main injection duration. Moreover, both blends had a lower $\mathrm{CN}$ in comparison with diesel (see Table 2), which extended the ID period and boosted the maximum pressure. Additionally, the heating value of E15FTD50B35 had a significant effect on the increased pressure. This trend was recently reported by a similar study [17].

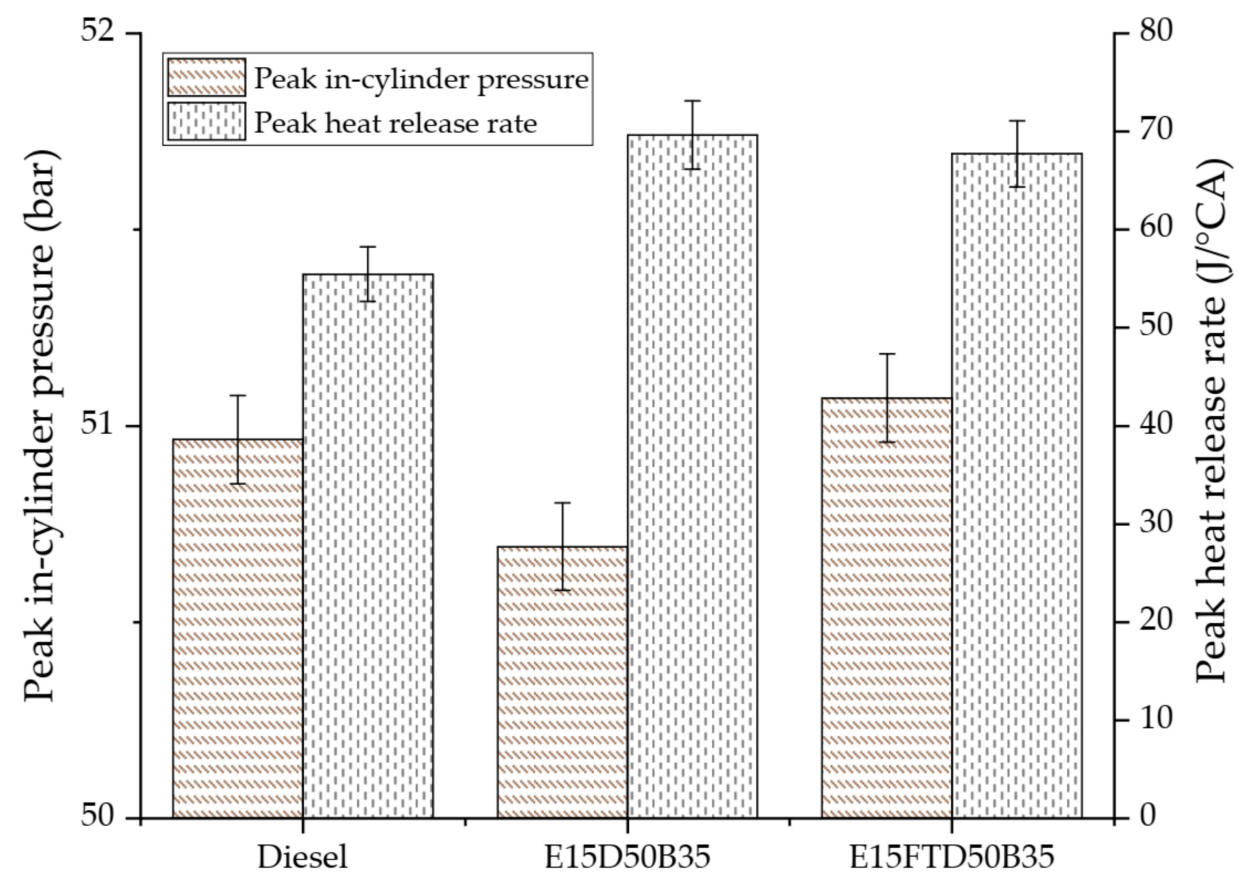

Figure 4. Peak in-cylinder pressure and peak heat release for diesel, E15D50B35, and E15FTD50B35 at 2 bar IMEP and $1500 \mathrm{rpm}$.

As for the peak HRR, both fuel blends had higher energy release in the premixed combustion phase compared to diesel. Furthermore, E15D50B35 presented the higher peak HRR among the fuels and a slight increase of 2.85\% in peak HRR as related to E15FTD50B35. Again, the longer ID due to ethanol addition leads to a longer F/A mixture time and thus more fuel burnt in the premixed combustion phase, which results in a higher peak of HRR compared to diesel combustion, although at a slightly later time.

The variation of ID and the duration of combustion are presented in Figure 5. The ID is a parameter that has a direct influence on engine performance, and that is affected by many parameters (e.g., CN, F/A ratio, injection timing, in-cylinder temperature). Similarly, the duration of combustion relies on parameters such as equivalence ratio, compression ratio, engine operational conditions, and fuel. A higher ID is observed for both blends E15D50B35 and E15FTD50B35. Longer ID could be explained by the lower CN (as seen in Table 2) and the high latent heat of vaporization of ethanol, thus leading to longer air and fuel mixing time and lower temperatures during compression. Hence, more fuel is burned in the premixed phase, which results in a higher maximum HRR (see Figure 4).

Various discussions of ID for ethanol/diesel/biodiesel blends are found in the literature [32,33]. Furthermore, in comparison with E15D50B35, the F-T diesel blend had a similar, although slightly lower ID. The reason for this is due to the higher CN of F-T diesel in comparison with pure diesel fuel, hence lowering the ID of the blend [34]. With the addition of ethanol, the duration of combustion decreased for both E15D50B35 and E15FTD50B35, due to the increase in the ID, probably as a result of the higher latent heat of vaporization of the ethanol. 


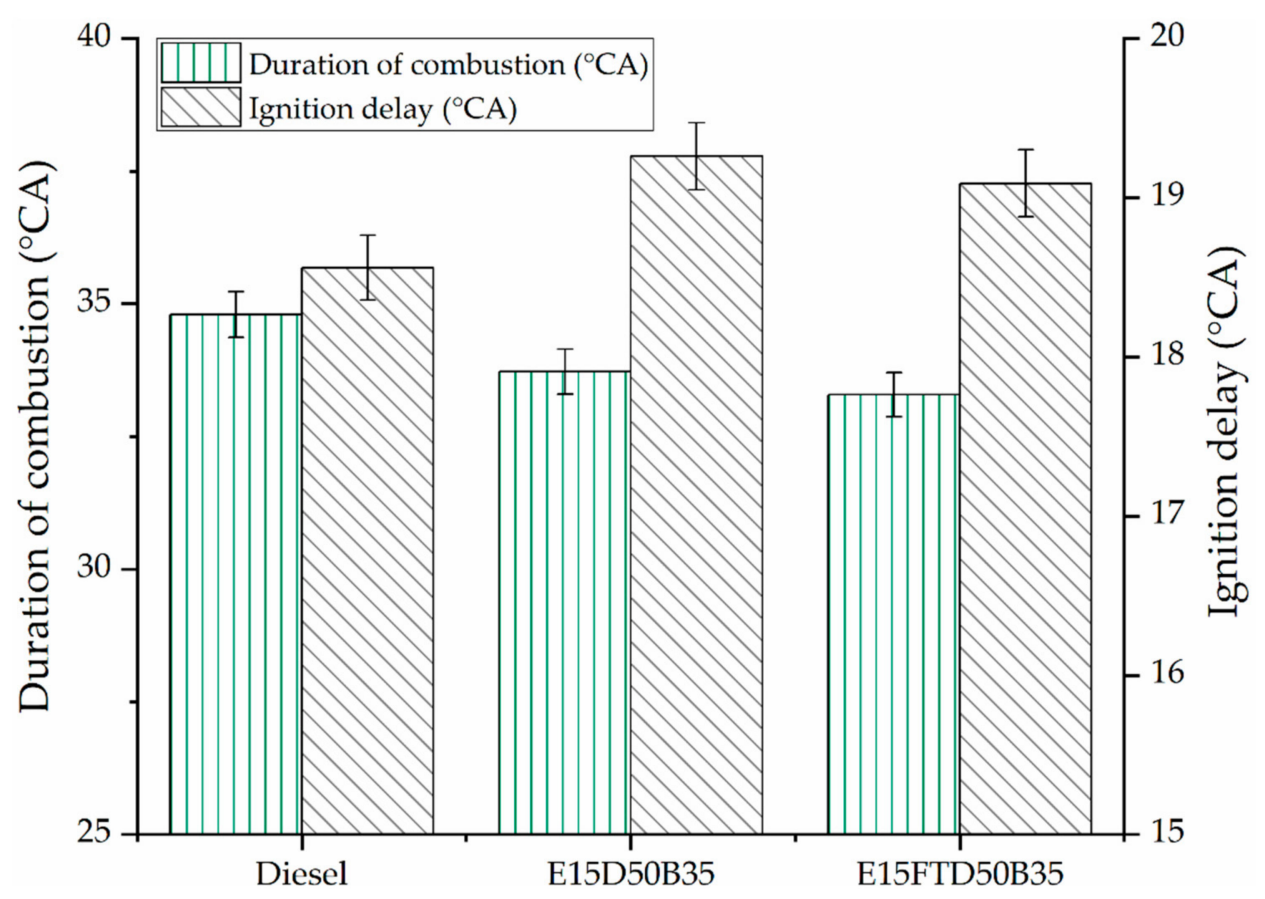

Figure 5. Duration of combustion and ignition delay for different fuels at 2 bar IMEP and $1500 \mathrm{rpm}$.

\subsection{Engine Exhaust Emissions}

Figure 6 shows the effects of fuel blends on $\mathrm{HC}, \mathrm{CO}$, and $\mathrm{NO}_{\mathrm{x}}$ when compared to conventional diesel fuel. The lack of oxygen in the chemical molecule of the fuel explains the higher THC emission for the conventional diesel. As for the E15D50B35 blend, it emitted 9\% less THC in comparison with diesel. Previous researchers have discussed the role of ethanol/biodiesel addition to diesel fuel as either increase [35] or decrease [36,37] HC emissions. When comparing the E15FTD50B35 fuel with the E15D50B35, the absence of aromatic hydrocarbons of the Fischer-Tropsch diesel, as well as his higher cetane number, further reduces THC exhaust emissions. Therefore, it can be noticed that the combustion of E15FTD50B35 produced the lowest THC emissions, which was $26 \%$ lower than the reference fuel and 19\% lower than the E15D50B35 blend. It has been previously reported that Fischer-Tropsch diesel reduces THC emission as it is a high reactivity fuel [38]. In other words, it has good auto-ignition qualities and a high cetane number, thus proving higher combustion efficiencies.

The oxygenated fuels are expected to reduce carbonaceous exhaust emissions as the presence of oxygen in fuel molecules eases hydrocarbon oxidation. However, the lower cetane number (because of ethanol) may conceivably increase exhaust emissions as a result of less time for the oxidation to occur and thus favoring incomplete combustion [39]. Additionally, the high latent heat of vaporization of ethanol could reduce the in-cylinder gas temperature, which decreases the oxidation reaction rate and thus increase $\mathrm{CO}$ emission under lower engine loads [40,41] as is the case for this research (Figure 6). Furthermore, the comparatively higher viscosity of biodiesel creates poor fuel atomization, which also contributes to incomplete combustion [42], and consequently increasing CO levels [43]. E15D50B35 and E15FTD50B35 have shown higher CO emissions with respect to diesel fuel. This can also be attributed to lower local in-cylinder temperature due to the ethanol cooling effect [44]. 


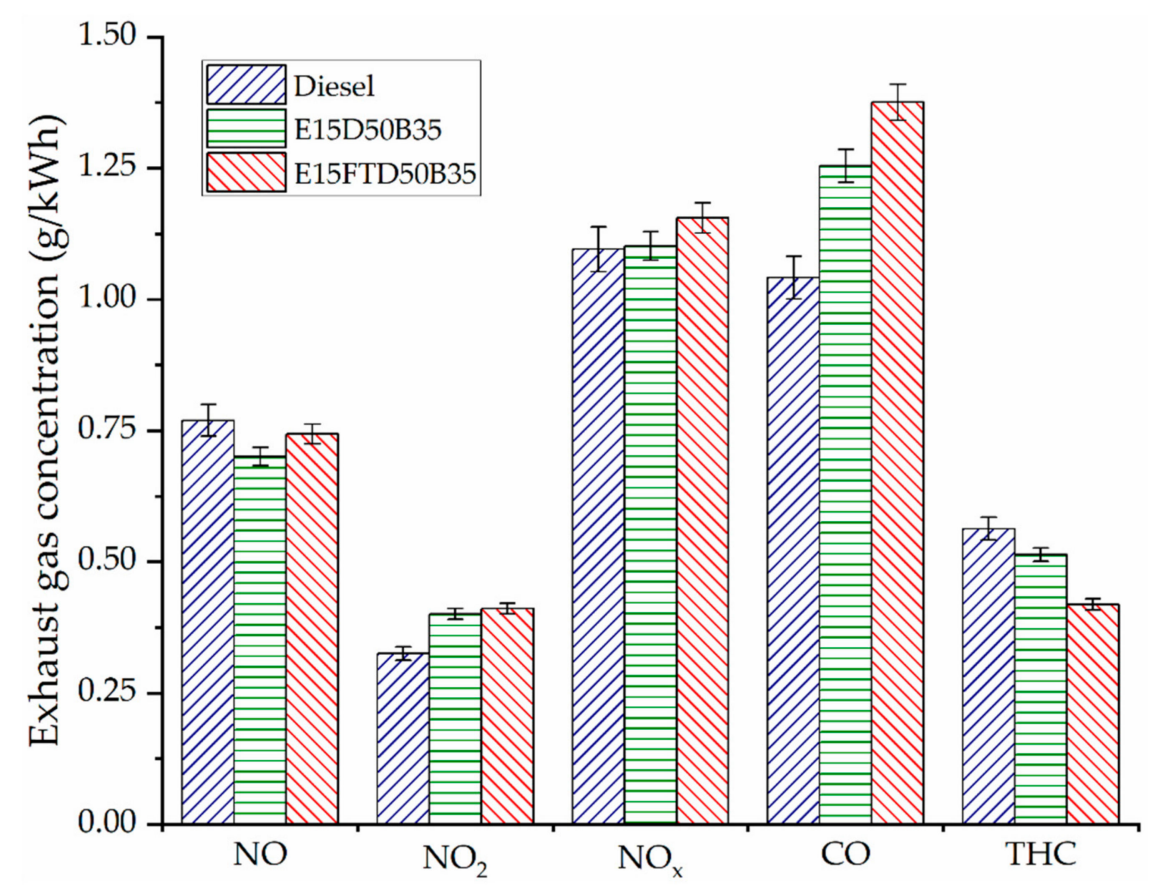

Figure 6. Effect of diesel, E15D50B35, and E15FTD50B35 on engine-out exhaust emissions at 2 bar IMEP and $1500 \mathrm{rpm}$.

Figure 6 shows the results of $\mathrm{NO}_{\mathrm{x}}$ exhaust emission for diesel, E15FTD50B35, and E15D50B35 at 2 bar IMEP and $1500 \mathrm{rpm}$. Previous works have discussed oxygenate fuel blends to mainly increase $\mathrm{NO}_{\mathrm{x}}$ emissions, e.g., [45,46], with some studies, having reported a slight reduction [47]. Among the factors that could influence these results are engine operating conditions and the presence of aromatics. Moreover, the effect of ethanol on lowering the cetane number of the blend, which means extending the ignition delay and increasing the amount of fuel that is burned in the premixed stage of combustion, increases $\mathrm{NO}_{\mathrm{x}}$ formation [46].

Additionally, amongst the reasons which can explain the trend of increased $\mathrm{NO}_{\mathrm{x}}$ for the oxygenated blends are the high oxygen content of the E15FTD50B35 and E15D50B35 blends (see Table 2). The higher oxygen content led to modified combustion patterns (Figure 3) and increased ignition delay. Additionally, it has been reported that the presence of aromatics may increase $\mathrm{NO}_{x}$ emissions, so the engine operating conditions must be considered [48]. The temperature is one of the major influences on $\mathrm{NO}_{\mathrm{x}}$, however the emissions depend on other parameters such as pressure, droplet sizes, type of combustion chamber, etc. For further details, please refer to the available literature $[49,50] . \mathrm{NO}_{\mathrm{x}}$ emissions of E15D50B35 and E15FTD50B35 are similar, although slightly higher (1\% and $5 \%$ for E15D50B35 and E15FTD50B35 blends respectively) than with diesel fuel (Figure 6).

\subsection{Impact of Biofuels on a Diesel Oxidation Catalyst (DOC)}

\subsubsection{CO Oxidation over a Diesel Oxidation Catalyst}

Figure 7 shows the catalyst $\mathrm{CO}$ light-off curves for all fuels. The engine exhaust emissions levels of $\mathrm{CO}$ from the combustion of conventional diesel are lower compared to the biofuel blends (as seen in Figure 6). Moreover, the THC emissions decreased for E15FTD50B35 and E15D50B35 in comparison with conventional diesel fuel (as seen in Figure 6). The high levels of $\mathrm{CO}$ in the engine-out emissions have slightly delayed the catalyst light-off activity. This is shown in Figure 7, as the temperature to reach is $50 \%$ of conversion efficiency is shifted to the right (i.e., higher temperatures than for the diesel fuel). This may be explained because $\mathrm{CO}$ can be adsorbed strongly in the catalyst and hence be the dominant species on the catalyst surface, which has been previously reported in the literature [51]. Moreover, Pt-group metals only show sufficiently high activity 
for $\mathrm{CO}$ oxidation above $\sim 150{ }^{\circ} \mathrm{C}$, which suggests that catalytic oxidation of $\mathrm{CO}$ may be kinetically limited at low temperatures [52]. Therefore, $\mathrm{CO}$ could self-inhibit the start of $\mathrm{CO}$ oxidation on the DOC catalyst, thus shifting the light-off into higher temperatures (Figure 8). It has been previously explained in the literature that at lower temperatures higher concentrations of $\mathrm{CO}$ inhibit the rate of reaction in the catalyst. Although, as the reactant is oxidized at higher temperatures, the rate of reaction is increased [53]. A similar trend was previously reported for butanol/biodiesel/diesel blend and pure biodiesel when compared to conventional diesel, as the latter had earlier catalyst light-off than the oxygenated fuel blends [23].

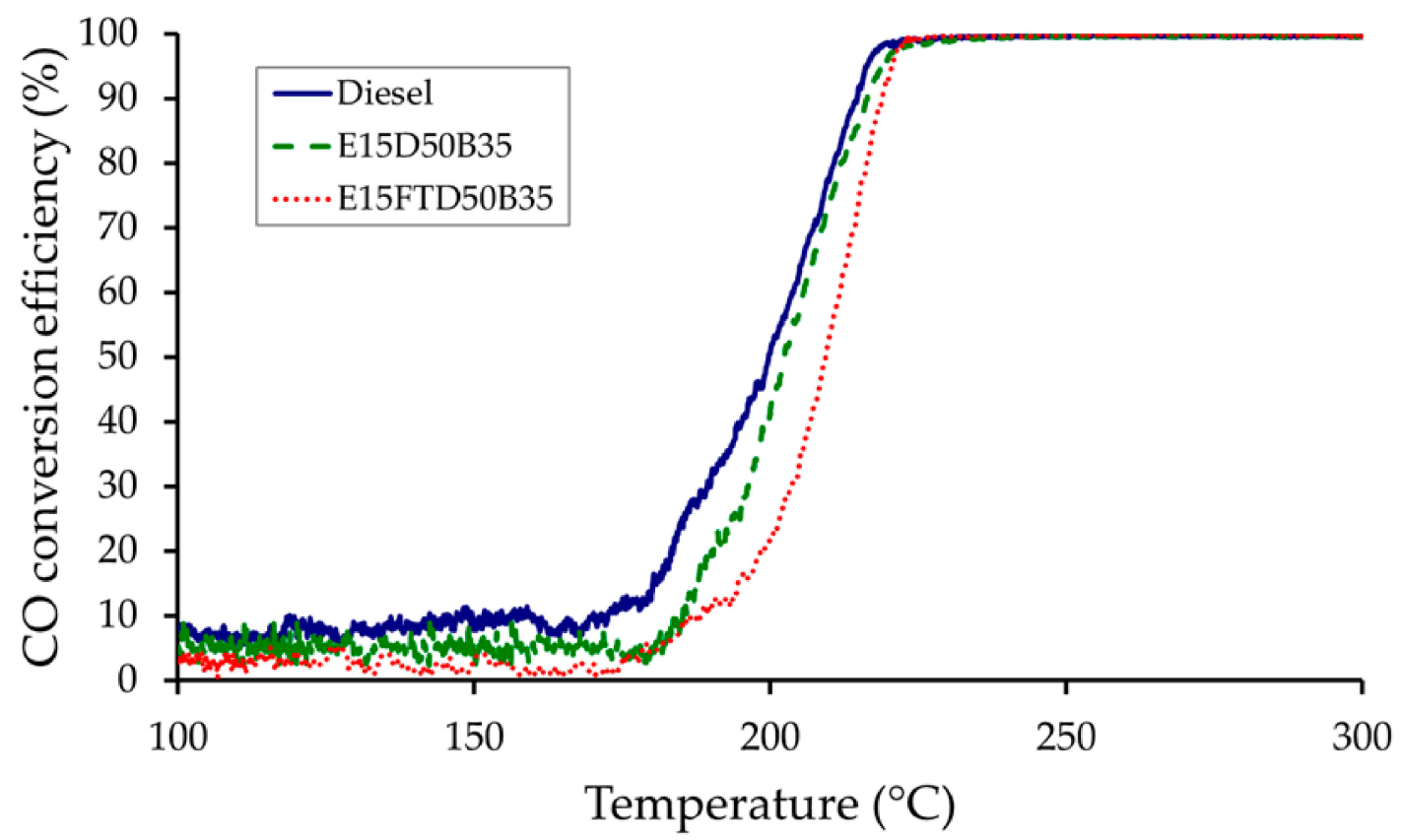

Figure 7. CO light-off curves from the exhaust gas produced for diesel, E15D50B35, and E15FTD50B35 at 2 bar IMEP and $1500 \mathrm{rpm}$.

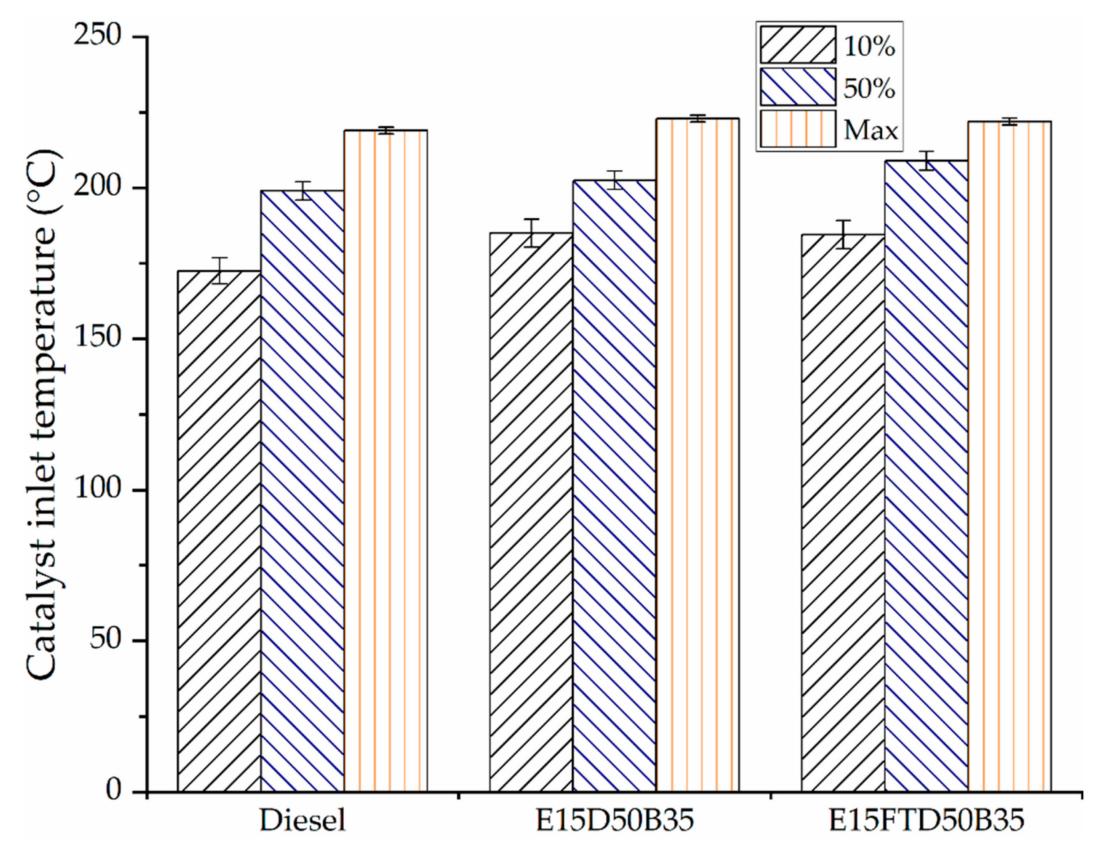

Figure 8. Diesel oxidation catalyst (DOC) inlet temperature that was required to reach $10 \%, 50 \%$, and maximum CO conversion for diesel, E15D50B35, and E15FTD50B35 at 2 bar IMEP and 1500 rpm. 
Furthermore, competitive adsorption on the same active sites by hydrocarbons (see Figure 9) and nitrogen oxide (see Figure 10) promotes reciprocal inhibition by each other and thus affecting $\mathrm{CO}$ oxidation $[54,55]$. Previous reports have discussed that both $\mathrm{NO}$ and $\mathrm{NO} 2$ can quickly adsorb and dissociate towards $\mathrm{Pt}$ and $\mathrm{Pd}$ active sites. This may generate a high coverage of adsorbed nitrogen species and oxygen atoms on the active sites which limits $\mathrm{CO}$ adsorption. As a result, adsorption competition may difficult $\mathrm{CO}$ access to the catalyst's active sites limiting the oxidation of CO. [51,56].

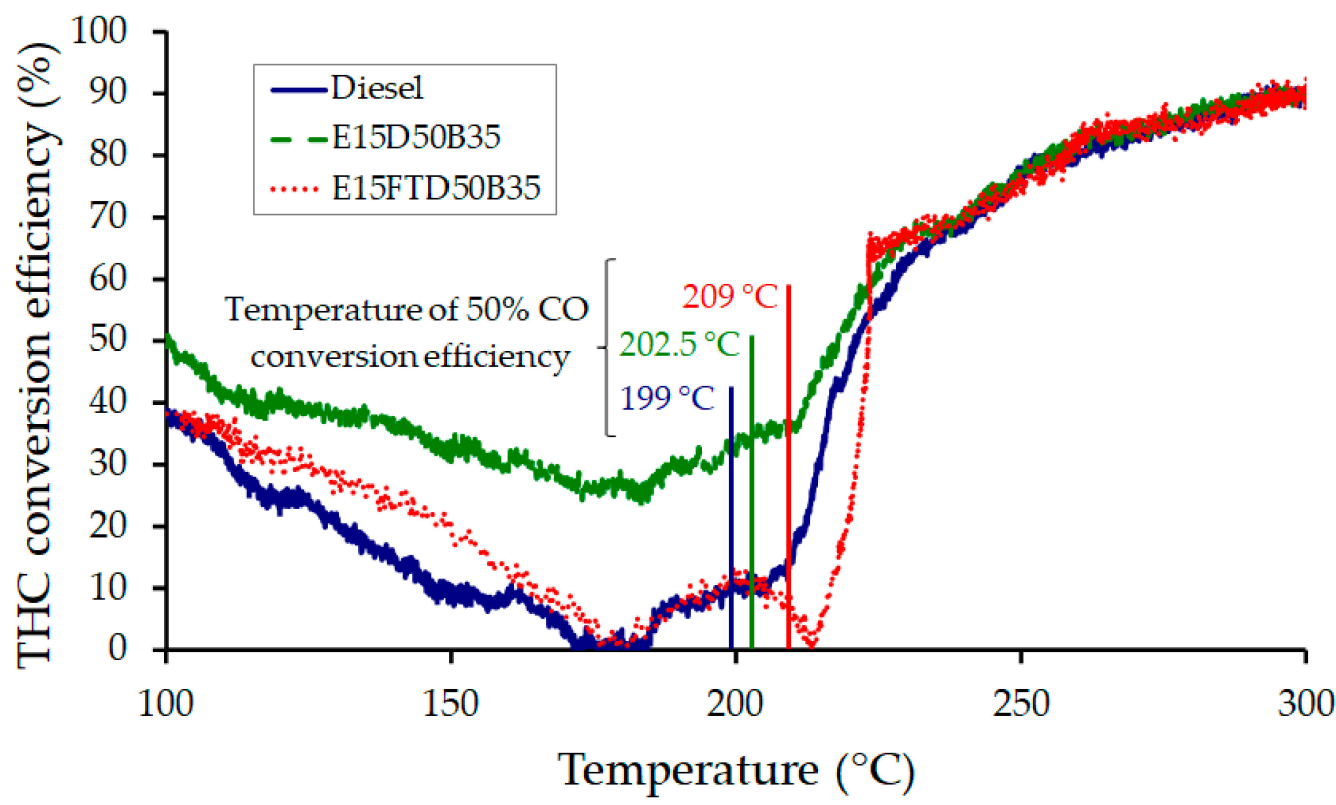

Figure 9. Total hydrocarbons (THC) light-off curves from diesel, E15D50B35, and E15FTD50B35 combustion at 2 bar IMEP and $1500 \mathrm{rpm}$.

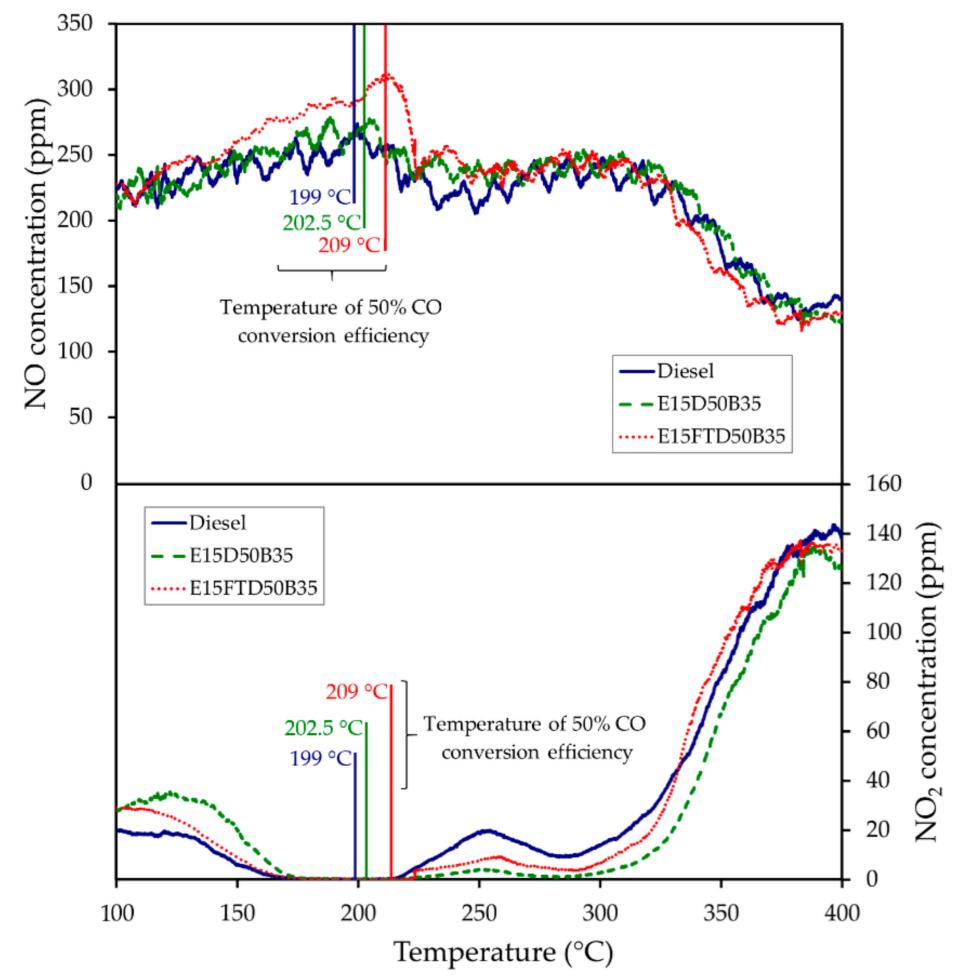

Figure 10. $\mathrm{NO}$ and $\mathrm{NO}_{2}$ downstream DOC catalyst at 2 bar IMEP and $1500 \mathrm{rpm}$. 
As observed in the emission results, the combustion of E15FTD50B35 produced higher $\mathrm{CO}$ exhaust emissions in comparison with diesel fuel and E15D50B35. Hence, as soon as oxidation starts, it increases the local catalyst's temperature and activity and therefore increases the $\mathrm{CO}$ oxidation reaction rate. Consequently, although this synthetic alternative fuel blend presented later light-off, it reached the maximum conversion efficiency in a lower temperature difference than the other tested fuels, as seen in Figure 8.

\subsubsection{THC Oxidation over a Diesel Oxidation Catalyst}

Figure 9 shows the total hydrocarbon conversion efficiency from the combustion of different fuels. Hydrocarbon conversion at low catalyst temperatures over the diesel oxidation catalyst should be considered a "virtual conversion", because it is a result of the trapping effect by catalyst zeolites, once the hydrocarbons are not exactly oxidized, but just temporarily kept over the catalyst zeolites [23,56]. It has been previously discussed that $\mathrm{CO}$ is considered as an inhibitor for itself and the oxidation of other species.

It is possible to observe in Figures 7 and 9 that hydrocarbon oxidation is promoted after the maximum rate of oxidation is reached for $\mathrm{CO}$. As $\mathrm{CO}$ oxidation over the DOC catalyst increases due to a rise in reaction temperature, hydrocarbon adsorption starts onto catalyst active sites. Further, it seems that, for all fuels, the start of hydrocarbon oxidation only occurs when at least $50 \%$ of the $\mathrm{CO}$ has been oxidized. The THC light-off curves seem to show that between $170{ }^{\circ} \mathrm{C}$ to $230{ }^{\circ} \mathrm{C}$ there is a plateau in conversion efficiency for the E15D50B35. Moreover, the graph illustrates that there was no conversion efficiency around $180{ }^{\circ} \mathrm{C}$ for diesel and E15FTD50B35. At this temperature interval $\left(170-230{ }^{\circ} \mathrm{C}\right)$, the rate of conversion efficiency decreased to a minimum value, as there were fluctuations in the oxidation reactions in the DOC catalyst. It should be noticed that this specific temperature interval is correlated with $\mathrm{CO}$ oxidation interval from the required temperature to reach $10 \%$ conversion efficiency to its maximum conversion, previously shown in Figure 8.

Furthermore, the higher conversion efficiency of THC was noticed for the E15D50B35 in comparison with the diesel fuel. This may be explained, as the blend is expected to have lower aromatic hydrocarbons than pure diesel, which have been reported to be more difficult to be adsorbed and oxidized [57-59]. Additionally, it has been formerly discussed that $\mathrm{NO}$ could compete with $\mathrm{HC}$ for adsorption over the catalyst, thus limiting hydrocarbon oxidation [56,60]. Moreover, the hydrocarbons from E15FTD50B35 exhaust combustion gas had been limited to start their oxidation only when $\mathrm{CO}$ has reached nearly maximum conversion efficiency. On the other hand, the conversion of HC for E15FTD50B35 increases and reaches a higher level of conversion efficiency immediately after $\mathrm{CO}$ has fully oxidized over the catalyst's active sites.

\subsection{3. $\mathrm{NO}$ to $\mathrm{NO}_{2}$ Oxidation over DOC Catalyst}

Figure 10 shows the oxidation of $\mathrm{NO}$ to $\mathrm{NO}_{2}$ in the DOC catalyst. This reaction is directly affected by the concentration of $\mathrm{CO}, \mathrm{THC}$, and $\mathrm{NO}$ in the exhaust. The results have shown that at low temperatures, $\mathrm{NO}_{2}$ is reacting with $\mathrm{CO}$ and $\mathrm{HC}$ in the catalyst since the concentration of $\mathrm{NO}_{2}$ is lower than the engine-out exhaust emission (see Figure 6).

Once $\mathrm{O}_{2}$ has oxidized $\mathrm{CO}$, it was observed an increase in $\mathrm{NO}_{2}$ concentration for all fuels nearly at the same temperature, around $220^{\circ} \mathrm{C}$. It should be noticed that the higher $\mathrm{NO}_{2}$ production at low temperatures is possibly due to the oxygenated components of the E15FTD50B35 and the E15D50B35 fuels, which could enhance the formation of active oxygenated components to produce $\mathrm{NO}_{2}$ [61].

The $\mathrm{NO}_{2}$ concentration starts to increase downstream of the DOC oxidation catalyst at around the same temperature of approximately $290{ }^{\circ} \mathrm{C}$ for all fuels, once the CO and THC have been completely oxidized in the catalyst active sites. Therefore, it is clear that the inhibition of carbonaceous emission on $\mathrm{NO}_{2}$ production occupying the catalyst active sites and consequently the consumption of any $\mathrm{NO}_{2}$ resulted from the combustion reaction with $\mathrm{CO}$ and $\mathrm{THC}$ to form $\mathrm{CO}_{2}$ [23]. 


\subsection{Particle Size Distribution}

Figure 11a shows the particle size distributions (PSD) resulting from the combustion of diesel, E15D50B35, and E15FTD50B35. According to the results, for most of the particle sizes, the concentration from diesel combustion is significantly higher than that obtained from the combustion of E15D50B35 and E15FTD50B35. The lower particulate number concentration resulting from the combustion of ethanol/diesel/biodiesel blend when compared to diesel fuel has been previously reported in the literature $[33,62]$.

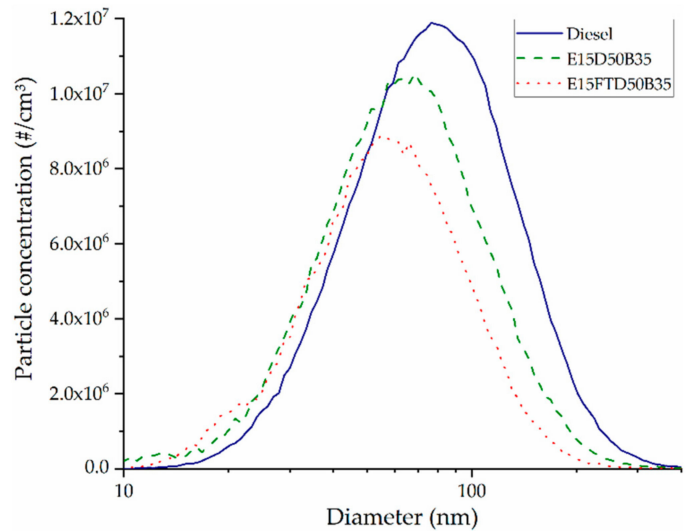

(a)

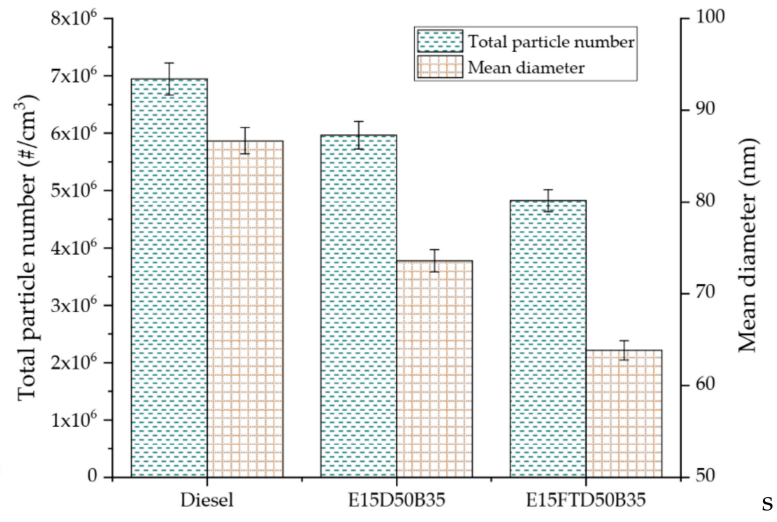

(b)

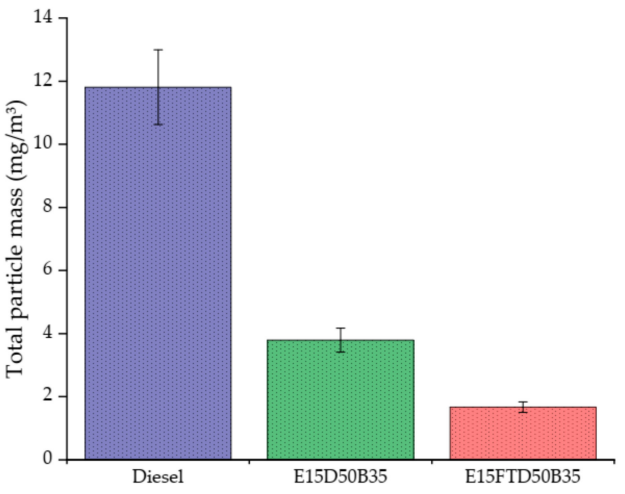

(c)

Figure 11. Effects of diesel, E15D50B35, and E15FTD50B35 on: (a) particle size distribution, (b) total particle number and mean diameter, and (c) total particle mass at 2 bar IMEP and $1500 \mathrm{rpm}$.

In addition, it may be noticed that the PM concentration of the E15FTD50B35 blend is lower than the E15D50B35 blend (Figure 11a). The oxygen present in the hydroxyl group of ethanol and the ester group of biodiesel, the lower content of aromatics with respect to diesel fuel, and the longer proportion of premixed combustion leading to a lower number of rich in fuel regions are the main responsible to reduce particle precursors and particles themselves [63].

Despite E15FTD50B35 and E15D50B35 having the same oxygen content (9.0 wt \%), the Fischer-Tropsch diesel composition does not have aromatics [64], which further contributes to reducing the particulate number emitted during the combustion process. Furthermore, Figure $11 \mathrm{~b}$ shows that the reduction in total particle number was $14 \pm 1.7 \%$ and $31 \pm 1.6 \%$ respectively for E15D50B35 and E15FTD50B35 blend in comparison with conventional diesel.

Figure 11c shows an estimative of the total particle mass concentration for diesel, E15D50B35, and E15FTD based on the number of particle size distribution particles. An effective particle density function enabled the calculation of an apparent particle density [65]. The particle mass result indicates that both blends had reduced the PM emissions in comparison with diesel fuel by $68 \pm 1.6 \%$ and $86 \pm 1.6 \%$, respectively for E15D50B35 
and E15FTD50B35. Furthermore, it is clear that E15FTD50B35 is an advantageous fuel for lowering particulate matter emissions in comparison with diesel.

Regarding the mean particle diameter, the results suggest that both E15FTD50B35 and E15D50B35 produce a reduction of the particle mean diameter in comparison with diesel of approximately $15 \pm 1.7 \%$ and $26 \pm 1.6$, respectively. The reduction in the mean particle size can be particularly explained by a significant reduction in the number of large particles. This was possibly a result of a lower likelihood of particle collision and the formation of larger particulate matter agglomerates $[11,24]$ rather than by an increase in the number of small size particle concentrations, which are more difficult to trap and are commonly associated with human health issues [66]. In conclusion, the use of both bio blends resulted in the slight shifting of the particle concentration curve to lower particles due to the use of oxygenated fuels (i.e., ethanol and biodiesel) [67], as is indicated in Figure 11a.

\section{Conclusions}

In this study, the effects of alternative (ethanol, biodiesel) and synthetic (FischerTropsch) diesel fuels on engine combustion exhaust gaseous, particulate emissions formation and characteristics, and aftertreatment system performance were investigated. It was found that the F-T diesel and ethanol blend can be designed to conform with the current diesel fuel standards provided that biodiesel is added to the mixture to overcome miscibility problems and to improve the lubricity of the fuel blend.

The blend containing F-T diesel (E15FTD50B35) resulted in significantly lower levels of THC and NO in the engine exhaust emissions when compared to the blend containing fossil diesel (E15D50B35) and much lower when compared to straight "pump" diesel. However, the lower cetane number and higher latent heat of vaporization of ethanol possibly created an undesired increase in $\mathrm{CO}$ emissions in comparison with the reference fuel. It has been found that the emissions of $\mathrm{NO}_{\mathrm{x}}$ slightly increased by 5\% for the E15FTD50B35 blend in comparison with the reference fuel and $4 \%$ for the E15D50B35 blend.

The diesel oxidation catalyst has effectively reduced the levels of $\mathrm{CO}$ and THC in the exhaust, as well as NO emissions. It was found that the DOC catalyst temperatures lightoff of the blended fuels have shifted to higher values due to the increased $\mathrm{CO}$ emissions present in the engine exhaust gases.

The combustion of the alternative fuels reduced PM number and mass concentrations, particularly the blend containing both ethanol and F-T diesel. The total particle number and mass concentrations emitted from E15FTD50B35 combustion were lower than the E15D50B35 blend and much lower than the diesel fuel. It may be inferred that the oxygen content of ethanol promotes positive effects on reducing the emissions of PM. Besides, the blend of ethanol, biodiesel with the incorporation of F-T diesel demonstrated to be more effective than the blend of ethanol/diesel/biodiesel in providing substantial benefit to engine combustion and particle emission levels. By keeping the same oxygen content in the fuel blends it was possible to observe the benefit of the higher cetane number and the absence of aromatic of the synthetic (F-T) fuel with respect to conventional diesel.

The main conclusion of this work is that it became clear that ethanol, biodiesel, and Fischer-Tropsch diesel fuels have individual properties that, when combined, have a potential for particulate emission-reducing along with aftertreatment systems and injection strategies promoting benefits for the engine combustion, as future emissions legislation standards are foreseen to be more stringent. Nevertheless, further research should be carried out on aspects of the properties of the biofuels, because such effects as the impact of ethanol and F-T diesel on lubricity were not studied in this research. Additionally, future work shall cover different injection strategies (i.e., injection pressure and post injection) and influence of EGR, as well as the effect of the blends on others aftertreatment devices efficiency (i.e., DPF and SCR catalysts).

Thus, it can be concluded that the use of alternative and sustainable fuels such as biofuels to attend the transport sector contributes to the effort to minimizing the pollution and the fossil-based $\mathrm{CO}_{2}$ emitted by ICE. 
Author Contributions: Conceptualization, F.A.T., O.D., J.M.H. and A.T.; methodology, F.A.T., O.D. and J.M.H.; formal analysis, F.A.T., O.D. and R.L.; investigation, F.A.T., O.D., R.L. and R.P.; resources, A.T.; writing - original draft preparation, F.A.T.; writing—review and editing, O.D., J.M.H., A.T., J.M. and S.A.B.V.d.M.; supervision, A.T., J.M. and S.A.B.V.d.M.; project administration, S.A.B.V.d.M.; funding acquisition, S.A.B.V.d.M. All authors have read and agreed to the published version of the manuscript.

Funding: This research received no external funding.

Institutional Review Board Statement: Not applicable.

Informed Consent Statement: Not applicable.

Data Availability Statement: Not applicable.

Acknowledgments: The University of Birmingham is gratefully acknowledged for the collaborative project under the International Cooperation Program with the Coordenação de Aperfeiçoamento de Pessoal de Nivel Superior-Brasil (CAPES) (Ref. No. 40/2014). The experimental work was conducted in the Future Engines \& Fuels Lab, University of Birmingham. Felipe Andrade Torres (F.A.T.) is deeply grateful to the laboratory managers, staff, and researchers for their hospitability, time, suggestions, reviews, and support during all the research period in the UK. The Coordenação de Aperfeiçoamento de Pessoal de Nivel Superior-Brasil (CAPES)-Finance Code 001 is also acknowledged for the research scholarship period and maintenance grant (Ref. No. 88887.199341/2018-00) for F.A.T.

Conflicts of Interest: The authors declare no conflict of interest.

\begin{tabular}{ll} 
Abbreviations \\
BTDC & Before the top dead center \\
BTL & Biomass-to-liquid \\
CA & Crank angle \\
CAD & Crank angle degree \\
CN & Cetane number \\
CO & Carbon monoxide \\
CO & Carbon dioxide \\
CPC & Condensation particle counter \\
CTL & Coal-to-liquid \\
DMA & Differential mobility analyzer \\
DOC & Diesel oxidation catalyst \\
FTIR & Fourier Transform Infrared \\
GHSV & Gas hourly space velocity \\
GTL & Gas-to-liquid \\
HC & Hydrocarbon \\
HRR & Heat release rate \\
ICE & Internal combustion engines \\
ID & Ignition delay \\
IMEP & Indicated mean effective pressure \\
ISEC & Indicated specific energy consumption \\
ISFC & Indicated specific fuel consumption \\
LHV & Lower heating value \\
NO & Nitrogen oxide \\
NO 2 & Nitrogen dioxide \\
NOx & Nitrogen oxides \\
PM & Particulate matter \\
PSD & Particle size distribution \\
SMPS & Scanning Mobility Particle Sizer \\
THC & Total hydrocarbons \\
ULSD & Ultra-low sulfur diesel \\
& \\
\hline
\end{tabular}




\section{References}

1. International Energy Agency (IEA). World Oil Final Consumption by Sector. Available online: https://www.iea.org/reports/ key-world-energy-statistics-2020/final-consumption (accessed on 21 October 2020).

2. Kalghatgi, G. Is it really the end of internal combustion engines and petroleum in transport? Appl. Energy 2018, 225, 965-974. [CrossRef]

3. Unglert, M.; Bockey, D.; Bofinger, C.; Buchholz, B.; Fisch, G.; Luther, R.; Müller, M.; Schaper, K.; Schmitt, J.; Schröder, O.; et al. Action areas and the need for research in biofuels. Fuel 2020, 268, 117227. [CrossRef]

4. Puškár, M.; Kopas, M. System based on thermal control of the HCCI technology developed for reduction of the vehicle NOX emissions in order to fulfil the future standard Euro 7. Sci. Total Environ. 2018, 643, 674-680. [CrossRef] [PubMed]

5. Çelebi, Y.; Aydın, H. An overview on the light alcohol fuels in diesel engines. Fuel 2019, 236, 890-911. [CrossRef]

6. De Oliveira, A.; de Morais, A.M.; Valente, O.S.; Sodré, J.R. Combustion characteristics, performance and emissions from a diesel power generator fuelled by B7-ethanol blends. Fuel Process. Technol. 2015, 139, 67-72. [CrossRef]

7. Mahmoudi, H.; Jahangiri, H.; Doustdar, O.; Akbari, N.; Wood, J.; Tsolakis, A.; Wyszynski, M.L. Maximizing paraffin to olefin ratio employing simulated nitrogen-rich syngas via Fischer-Tropsch process over Co3O4/SiO2 catalysts. Fuel Process. Technol. 2020, 208, 106477. [CrossRef]

8. Okoye-Chine, C.G.; Moyo, M.; Liu, X.; Hildebrandt, D. A critical review of the impact of water on cobalt-based catalysts in Fischer-Tropsch synthesis. Fuel Process. Technol. 2019, 192, 105-129. [CrossRef]

9. Zhang, Y.; Mathieu, O.; Petersen, E.L.; Bourque, G.; Curran, H.J. Assessing the predictions of a NO x kinetic mechanism on recent hydrogen and syngas experimental data. Combust. Flame 2017, 182, 122-141. [CrossRef]

10. Sajjad, H.; Masjuki, H.H.; Varman, M.; Khan, M.M.R.; Arbab, M.I.; Imtenan, S.; Sanjid, A. Comparative Study of Biodiesel, GTL Fuel and Their Blends in Context of Engine Performance and Exhaust Emission. Procedia Eng. 2014, 90, 466-471. [CrossRef]

11. Lapuerta, M.; Armas, O.; Hernández, J.J.; Tsolakis, A. Potential for reducing emissions in a diesel engine by fuelling with conventional biodiesel and Fischer-Tropsch diesel. Fuel 2010, 89, 3106-3113. [CrossRef]

12. Sajjad, H.; Masjuki, H.H.; Varman, M.; Kalam, M.A.; Arbab, M.I.; Imtenan, S.; Ashraful, A.M. Influence of gas-to-liquid (GTL) fuel in the blends of Calophyllum inophyllum biodiesel and diesel: An analysis of combustion-performance-emission characteristics. Energy Convers. Manag. 2015, 97, 42-52. [CrossRef]

13. Soloiu, V.; Gaubert, R.; Moncada, J.; Wiley, J.; Williams, J.; Harp, S.; Ilie, M.; Molina, G.; Mothershed, D. Reactivity controlled compression ignition and low temperature combustion of Fischer-Tropsch Fuel Blended with n-butanol. Renew. Energy 2019, 134, 1173-1189. [CrossRef]

14. Lapuerta, M.; Rodríguez-Fernandez, J.; García-Contreras, R.; Bogarra, M. Molecular interactions in blends of alcohols with diesel fuels: Effect on stability and distillation. Fuel 2015, 139, 171-179. [CrossRef]

15. Sun, D.; Wang, T.; Cao, Y.; Yang, T.; Jiang, Q.; Fan, B. The Influence of F-T Diesel/Methanol Micro-Emulsified Fuels on Emission Characteristics of a Diesel Engine. Chin. Intern. Combust. Engine Eng. 2017, 38, 41-51.

16. Yang, T.; Wang, T.; Qiao, J.; Gao, J.; Feng, Y.; Sun, D. Influence of the Methanol Proportion on the Combustion Characteristics of Methanol-Biodiesel -F-T Diesel Blended Fuel. In SAE Technical Papers; SAE International: Warrendale, PA, USA, 2017 ; Volume 1.

17. Jiao, Y.; Liu, R.; Zhang, Z.; Yang, C.; Zhou, G.; Dong, S.; Liu, W. Comparison of combustion and emission characteristics of a diesel engine fueled with diesel and methanol-Fischer-Tropsch diesel-biodiesel-diesel blends at various altitudes. Fuel 2019, 243, 52-59. [CrossRef]

18. Rodríguez-Fernández, J.; Tsolakis, A.; Theinnoi, K.; Snowball, J.; Sawtell, A.; York, A.P.E. Engine Performance and Emissions from Dual Fuelled Engine with In-Cylinder Injected Diesel Fuels and In-Port Injected Bioethanol. In SAE Technical Papers; SAE International: Warrendale, PA, USA, 2009. [CrossRef]

19. May-Carle, J.-B.; Pidol, L.; Nicolle, A.; Anderlohr, J.M.; Togbé, C.; Dagaut, P. Experimental and Numerical Study of FT/Biodiesel/Bioethanol Surrogate Fuel Oxidation in Jet-Stirred Reactor. Combust. Sci. Technol. 2012, 184, 901-915. [CrossRef]

20. Pidol, L.; Lecointe, B.; Starck, L.; Jeuland, N. Ethanol-biodiesel-Diesel fuel blends: Performances and emissions in conventional Diesel and advanced Low Temperature Combustions. Fuel 2012, 93, 329-338. [CrossRef]

21. Martins, J.; Brito, F.P. Alternative fuels for internal combustion engines. Energies 2020, 13, 4086. [CrossRef]

22. Fayad, M.A.; Tsolakis, A.; Martos, F.J. Influence of alternative fuels on combustion and characteristics of particulate matter morphology in a compression ignition diesel engine. Renew. Energy 2020, 149, 962-969. [CrossRef]

23. Fayad, M.A.; Herreros, J.M.; Martos, F.J.; Tsolakis, A. Role of Alternative Fuels on Particulate Matter (PM) Characteristics and Influence of the Diesel Oxidation Catalyst. Environ. Sci. Technol. 2015, 49, 11967-11973. [CrossRef]

24. Herreros, J.M.; Schroer, K.; Sukjit, E.; Tsolakis, A. Extending the environmental benefits of ethanol-diesel blends through DGE incorporation. Appl. Energy 2015, 146, 335-343. [CrossRef]

25. Fayad, M.A.; Fernàndez-Rodríguez, D.; Herreros, J.M.; Lapuerta, M.; Tsolakis, A. Interactions between aftertreatment systems architecture and combustion of oxygenated fuels for improved low temperature catalysts activity. Fuel 2018, 229, $189-197$. [CrossRef]

26. Hergueta, C.; Tsolakis, A.; Herreros, J.M.; Bogarra, M.; Price, E.; Simmance, K.; York, A.P.E.; Thompsett, D. Impact of bio-alcohol fuels combustion on particulate matter morphology from efficient gasoline direct injection engines. Appl. Energy 2018, 230, 794-802. [CrossRef]

27. Moffat, R.J. Describing the uncertainties in experimental results. Exp. Therm. Fluid Sci. 1988, 1, 3-17. [CrossRef] 
28. Pradelle, F.; Leal Braga, S.; Fonseca de Aguiar Martins, A.R.; Turkovics, F.; Nohra Chaar Pradelle, R. Performance and combustion characteristics of a compression ignition engine running on diesel-biodiesel-ethanol (DBE) blends-Potential as diesel fuel substitute on an Euro III engine. Renew. Energy 2019, 136, 586-598. [CrossRef]

29. Guarieiro, L.L.N.; de Almeida Guerreiro, E.T.; dos Santos Amparo, K.K.; Manera, V.B.; Regis, A.C.D.; Santos, A.G.; Ferreira, V.P.; Leão, D.J.; Torres, E.A.; de Andrade, J.B. Assessment of the use of oxygenated fuels on emissions and performance of a diesel engine. Microchem. J. 2014, 117, 94-99. [CrossRef]

30. Chacko, N.; Jeyaseelan, T. Comparative evaluation of graphene oxide and graphene nanoplatelets as fuel additives on the combustion and emission characteristics of a diesel engine fuelled with diesel and biodiesel blend. Fuel Process. Technol. 2020, 204, 106406. [CrossRef]

31. Jamuwa, D.K.; Sharma, D.; Soni, S.L. Experimental investigation of performance, exhaust emission and combustion parameters of stationary compression ignition engine using ethanol fumigation in dual fuel mode. Energy Convers. Manag. 2016, 115, 221-231. [CrossRef]

32. Shahir, S.A.; Masjuki, H.H.; Kalam, M.A.; Imran, A.; Ashraful, A.M. Performance and emission assessment of diesel-biodieselethanol/bioethanol blend as a fuel in diesel engines: A review. Renew. Sustain. Energy Rev. 2015, 48, 62-78. [CrossRef]

33. Tse, H.; Leung, C.W.; Cheung, C.S. Investigation on the combustion characteristics and particulate emissions from a diesel engine fueled with diesel-biodiesel-ethanol blends. Energy 2015, 83, 343-350. [CrossRef]

34. Gill, S.S.; Tsolakis, A.; Dearn, K.D.; Rodríguez-Fernández, J. Combustion characteristics and emissions of Fischer-Tropsch diesel fuels in IC engines. Prog. Energy Combust. Sci. 2011, 37, 503-523. [CrossRef]

35. Aydın, F.; Öğ̈̈t, H. Effects of using ethanol-biodiesel-diesel fuel in single cylinder diesel engine to engine performance and emissions. Renew. Energy 2017, 103, 688-694. [CrossRef]

36. Barabás, I.; Todoruţ, A.; Băldean, D. Performance and emission characteristics of an CI engine fueled with diesel-biodieselbioethanol blends. Fuel 2010, 89, 3827-3832. [CrossRef]

37. Roy, M.M.; Calder, J.; Wang, W.; Mangad, A.; Diniz, F.C.M. Cold start idle emissions from a modern Tier-4 turbo-charged diesel engine fueled with diesel-biodiesel, diesel-biodiesel-ethanol, and diesel-biodiesel-diethyl ether blends. Appl. Energy 2016, 180, 52-65. [CrossRef]

38. Khan, M.; Tafreshi, R.; Mokahal, A.J.; Mohamed, M.T.; Hanbal, M.Y.; Elturk, J. Single Cylinder GTL ENGINE: An Experimental Comparison between Traditional Diesel and GTL Diesel on Single Cylinder Engine. In SAE Technical Papers; SAE International: Warrendale, PA, USA, 2016. [CrossRef]

39. Herreros, J.M.; Jones, A.; Sukjit, E.; Tsolakis, A. Blending lignin-derived oxygenate in enhanced multi-component diesel fuel for improved emissions. Appl. Energy 2014, 116, 58-65. [CrossRef]

40. Zhu, L.; Cheung, C.S.; Zhang, W.G.; Huang, Z. Combustion, performance and emission characteristics of a DI diesel engine fueled with ethanol-biodiesel blends. Fuel 2011, 90, 1743-1750. [CrossRef]

41. Ribeiro, N.; Pinto, A.C.; Quintella, C.M.; da Rocha, G.O.; Teixeira, L.S.G.; Guarieiro, L.L.N.; do Carmo Rangel, M.; Veloso, M.C.C.; Rezende, M.J.C.; da Cruz, R.S.; et al. The role of additives for diesel and diesel blended (ethanol or biodiesel) fuels: A review. Energy Fuels 2007, 21, 2433-2445. [CrossRef]

42. Mofijur, M.; Rasul, M.G.; Hyde, J.; Azad, A.K.; Mamat, R.; Bhuiya, M.M.K. Role of biofuel and their binary (diesel-biodiesel) and ternary (ethanol-biodiesel-diesel) blends on internal combustion engines emission reduction. Renew. Sustain. Energy Rev. 2016, 53, 265-278. [CrossRef]

43. Gülüm, M.; Bilgin, A. A comprehensive study on measurement and prediction of viscosity of biodiesel-diesel-alcohol ternary blends. Energy 2018, 148, 341-361. [CrossRef]

44. Jamrozik, A.; Tutak, W.; Gnatowska, R.; Nowak, Ł. Comparative analysis of the combustion stability of diesel-methanol and diesel-ethanol in a dual fuel engine. Energies 2019, 12, 971. [CrossRef]

45. Armas, O.; García-Contreras, R.; Ramos, Á. Pollutant emissions from New European Driving Cycle with ethanol and butanol diesel blends. Fuel Process. Technol. 2014, 122, 64-71. [CrossRef]

46. Yilmaz, N.; Vigil, F.M.; Benalil, K.; Davis, S.M.; Calva, A. Effect of biodiesel-butanol fuel blends on emissions and performance characteristics of a diesel engine. Fuel 2014, 135, 46-50. [CrossRef]

47. Carvalho, M.; Torres, F.; Ferreira, V.; Silva, J.; Martins, J.; Torres, E. Effects of Diethyl Ether Introduction in Emissions and Performance of a Diesel Engine Fueled with Biodiesel-Ethanol Blends. Energies 2020, 13, 3787. [CrossRef]

48. Reijnders, J.; Boot, M.; de Goey, P. Impact of aromaticity and cetane number on the soot-NOx trade-off in conventional and low temperature combustion. Fuel 2016, 186, 24-34. [CrossRef]

49. Glarborg, P.; Miller, J.A.; Ruscic, B.; Klippenstein, S.J. Modeling nitrogen chemistry in combustion. Prog. Energy Combust. Sci. 2018, 67, 31-68. [CrossRef]

50. Ahmed, S.F.; Aghdam, A.C.; Dryer, F.L.; Farouk, T.I. Multidimensional simulations of Mckenna-driven flow tube configuration: Investigating non-ideality in NOx formation flow tube experiments. Combust. Flame 2021, 223, 511-524. [CrossRef]

51. Watling, T.C.; Ahmadinejad, M.; Tुuţuianu, M.; Johansson, Å.; Paterson, M.A.J. Development and Validation of a Pt-Pd Diesel Oxidation Catalyst Model. SAE Int. J. Engines 2012, 5, 1420-1442. [CrossRef]

52. Kim, I.H.; Seo, H.O.; Park, E.J.; Han, S.W.; Kim, Y.D. Low temperature CO oxidation over iron oxide nanoparticles decorating internal structures of a mesoporous alumina. Sci. Rep. 2017, 7, 1-11. [CrossRef] 
53. Ye, S.; Yap, Y.H.; Kolaczkowski, S.T.; Robinson, K.; Lukyanov, D. Catalyst 'light-off' experiments on a diesel oxidation catalyst connected to a diesel engine-Methodology and techniques. Chem. Eng. Res. Des. 2012, 90, 834-845. [CrossRef]

54. Al-Harbi, M.; Hayes, R.; Votsmeier, M.; Epling, W.S. Competitive no, co and hydrocarbon oxidation reactions over a diesel oxidation catalyst. Can. J. Chem. Eng. 2012, 90, 1527-1538. [CrossRef]

55. Oh, H.; Luo, J.; Epling, W.S. NO oxidation inhibition by hydrocarbons over a diesel oxidation catalyst: Reaction between surface nitrates and hydrocarbons. Catal. Lett. 2011, 141, 1746-1751. [CrossRef]

56. Lefort, I.; Herreros, J.M.; Tsolakis, A. Reduction of low temperature engine pollutants by understanding the exhaust species interactions in a diesel oxidation catalyst. Environ. Sci. Technol. 2014, 48, 2361-2367. [CrossRef]

57. Aydin, H.; Ilkiliç, C. Effect of ethanol blending with biodiesel on engine performance and exhaust emissions in a CI engine. Appl. Therm. Eng. 2010, 30, 1199-1204. [CrossRef]

58. Patterson, M.J.; Angove, D.E.; Cant, N.W. The effect of carbon monoxide on the oxidation of four C6 to C8 hydrocarbons over platinum, palladium and rhodium. Appl. Catal. B Environ. 2000, 26, 47-57. [CrossRef]

59. Demidyuk, V.; Hardacre, C.; Burch, R.; Mhadeshwar, A.; Norton, D.; Hancu, D. Aromatic hydrocarbons and sulfur based catalyst deactivation for selective catalytic reduction of NOx. Catal. Today 2011, 164, 515-519. [CrossRef]

60. Irani, K.; Epling, W.S.; Blint, R. Effect of hydrocarbon species on no oxidation over diesel oxidation catalysts. Appl. Catal. B Environ. 2009, 92, 422-428. [CrossRef]

61. Johnson, W.L.; Fisher, G.B.; Toops, T.J. Mechanistic investigation of ethanol SCR of NOx over Ag/Al2O3. Catal. Today 2012, 184, 166-177. [CrossRef]

62. Ghadikolaei, M.A.; Wei, L.; Cheung, C.S.; Yung, K.F.; Ning, Z. Particulate emission and physical properties of particulate matter emitted from a diesel engine fueled with ternary fuel (diesel-biodiesel-ethanol) in blended and fumigation modes. Fuel 2020, 263, 116665. [CrossRef]

63. Sukjit, E.; Herreros, J.M.; Dearn, K.; Tsolakis, A. Improving Ethanol-Diesel Blend Through the Use of Hydroxylated Biodiesel. In SAE Technical Papers; SAE International: Warrendale, PA, USA, 2014. [CrossRef]

64. Di, Y.; Cheung, C.S.; Huang, Z. Comparison of the Effect of Biodiesel-Diesel and Ethanol-Diesel on the Particulate Emissions of a Direct Injection Diesel Engine. Aerosol Sci. Technol. 2009, 43, 455-465. [CrossRef]

65. Lapuerta, M.; Armas, O.; Gómez, A. Diesel particle size distribution estimation from digital image analysis. Aerosol Sci. Technol. 2003, 37, 369-381. [CrossRef]

66. Zhang, Z.H.; Balasubramanian, R. Effects of oxygenated fuel blends on the composition of size-segregated engine-out diesel particulate emissions and on the toxicity of quasi-ultrafine particles. Fuel 2018, 215, 161-170. [CrossRef]

67. Tse, H.; Leung, C.W.; Cheung, C.S. Performances, Emissions and Soot Properties from a Diesel-Biodiesel-Ethanol Blend Fuelled Engine. Adv. Automob. Eng. 2016, 1, 1-7. [CrossRef] 